\section{Increasing Consumers' Hypermarket Visit Intention through Cause-Related Marketing: A Perspective from the Theory of Planned Behaviour}

\author{
Kay Tze Hong ${ }^{1}$ \\ Siew Imm Ng ${ }^{1}$ \\ Raja Nerina Raja Yusof ${ }^{1}$ \\ ${ }^{1}$ University Putra Malaysia, Department of Marketing \\ and Management, Serdang and Malaysia \\ Shivee Ranjanee Kaliappan ${ }^{2}$ \\ ${ }^{2}$ University Putra Malaysia, Department of Economics, Serdang and Malaysia
}

\begin{abstract}
Purpose - This study intends to discover factors affecting consumers' intention to participate in cause-related marketing (CRM) and how CRM influences their intention to visit hypermarkets in Malaysia.

Design/methodology/approach - Through a self-administered questionnaire and using a mall-intercept technique, a total of 460 samples were collected from consumers in Malaysia. Structural equation modelling was then used to analyse the data.

Findings - The results show that three variables (perceived CSR image, consumer-company identification and perceived company-cause fit) out of four significantly predicted consumers' attitude towards CRM. Also, two components (attitude and perceived behavioural control) out of three in the theory of planned behaviour were found to be significantly related to CRM participation intention. Lastly, CRM participation intention was found to influence hypermarket visit intention.
\end{abstract}

Originality/value - The proposed theory of planned behaviour (TPB) was found to be applicable in predicting CRM participation intention and hypermarket visit intention. The findings showed that consumers are more likely to increase their intention to visit a hypermarket that adopts a CRM campaign, which led us to highlight the main implications for hypermarket management and new study areas in this field.

Keywords - corporate social responsibility; cause-related marketing; hypermarket; visit intention; theory of planned behaviour
Received on

07/06/2017

Approved on

$12 / 27 / 2018$

Responsible editor:

Prof. Dr. Guilherme de Farias

Shiraishi

\section{Evaluation process:}

Double Blind Review

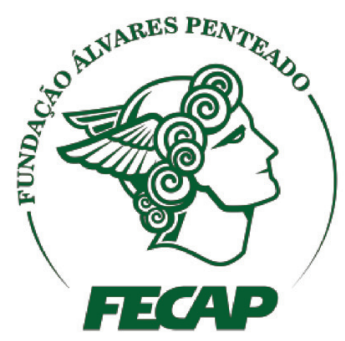

Review of Business

Management

DOI: $10.7819 /$ rbgn.v21i3.4008 


\section{Introduction}

The Malaysian retail sector is recognised as being the main contributor to the nation's gross national income (GNI) and has transformed throughout the years from small traditional retail shops to large modern retail format stores, such as hypermarkets, supermarkets and department stores (PEMANDU, 2013). Although Malaysia has faced weak economic conditions, grocery retailing has remained strong in its value growth (Euromonitor International, 2014). The resilience of the retail sector under such economic conditions attracts many players and creates intense competition. Therefore, retailers, including hypermarkets, need to manage consumers' expectations more effectively to remain relevant.

Given the increased awareness of corporate social responsibility (CSR) in general, consumers have expected hypermarkets to start showing initiatives in CSR-related activities (Saeidi et al., 2015). CSR has innovatively emerged as part of a firm's marketing strategy by linking CSR activities to sales objectives; this is called cause-related marketing (CRM). CRM has been welcomed by companies because it has fulfilled consumers' expectations and improved company performance and reputation while helping a social cause (Sen \& Bhattacharya, 2001). The applicability of CRM in the hypermarket context is under-reported. So far, CRM research has largely focused on specific retailers (Liu \& Ko, 2011), such as chocolate manufacturers (Moosmayer \& Fuljahn, 2010), fast-moving consumers goods (Patel et al., 2017), hotels (Boenigk \& Schuchardt, 2015) and restaurants (Hanks et al., 2016).

This study on CRM differs from others in two ways. First, others have focused on social cause or product factors, such as the influence of the social cause category on consumer perceptions (Lafferty \& Edmondson, 2014) and products of CRM with negative externalities possibly leading to unexpected effects (Grolleau et al., 2016). The literature that has looked at consumer and firm factors such as consumers' CRM attitude and the firm's CSR image is limited. Second, the research framework of CRM has so far focused on loose antecedents that directly affect CRM intention. In fact, many of these antecedents were factors that formed attitude towards CRM and attitude was reported to be the main driver of intention (Pookulangara et al., 2011), which is consistent with the proposal of the theory of planned behaviour (TPB). TPB may serve as a theoretical basis to understand CRM antecedents more meaningfully, but its use in the CRM context is scarce. Therefore, this study closes the gap in the literature by testing the applicability of TPB in explaining consumers' CRM participation intention and hypermarket visit intention.

This study investigates the effectiveness of CRM in consumers' hypermarket visit intention using the TPB model. Its components, namely attitude, subjective norm (SN) and perceived behavioural control (PBC), are used to evaluate consumers' response to CRM and hypermarket visit intention. This study contributes to the literature in three ways. First, it uses a novel social cause called "supporting underprivileged individuals", which has the ultimate aim of developing financially independent entrepreneurs. This social cause was created by this study based on suggestions from a focus group interview (forthcoming paper). The CRM literature has commonly focused on causes including diseases such as cancer (Robinson et al., 2012), wildlife and environmental causes such as the World Wildlife Fund and rainforest protection (Chéron et al., 2012), and the homeless (Chang, 2011).

The cause of supporting underprivileged individuals is relevant to a developing country like Malaysia as income distribution inequality is still high (The Star Online, 2013) and lower income groups need additional attention (The Star Online, 2016). Underprivileged individuals include single mothers, unskilled individuals and individuals that lack access to proper resources and food (Borneo Post Online, 2013; Malay Mail Online, 2016). By helping the underprivileged to 
support themselves, the country is also able to rise above the poverty line as a whole.

Second, the study contributes to the CRM literature by introducing a framework with a stronger theoretical background, that is, TPB. So far, CRM frameworks have not been rooted in a solid theoretical base. For example, most CRM studies have used multiple supporting theories, such as social identity theory (Vanhamme et al., 2012), attribution theory (Cui et al., 2003) and information integration theory (Samu \& Wymer, 2009), to explain individual construct relationships with consumers' response to CRM. Third, the study extends the use of CRM to the hypermarket context. The applicability of CRM in the hypermarket context can provide valuable insights for hypermarket managers. The antecedents, namely altruistic firm motives (AFM), consumer-company identification (CCI), perceived CSR image (CSRI) and perceived company-cause fit (CCF), are hypothesised to influence attitudes towards CRM, which can help managers make informed decisions on CRM implementation.

\section{Literature review}

\section{I CSR and CRM}

CSR is a tactic not only for fulfilling a company's moral obligation to the community, but also a way for the firm to align its interests with its stakeholders' to decrease risks and safeguard the continuity of the company's business (de Freitas Brandão et al., 2017). Patrus et al. (2013) asserted that a socially responsible company creates organizational values and seeks to improve the social conditions of people affected by its actions. Likewise, retailers that participate in CSR activities can positively enhance the relationship between retailer and customer (Potdar, Guthrie \& Gnoth, 2018). CSR has been studied from many different perspectives and in contexts such as the relationship between CSR and employees' perceptions (e.g. Azim, 2016; de Freitas Brandão et al., 2017), the positive influence of ownership concentration on CSR
(Crisóstomo \& Freire, 2015) and the relationship between consumers' CSR perception and social boycott (Cruz, 2017). This study focuses on the dimension of consumers' perceptions regarding the hypermarket's CSR initiatives (i.e. CRM) and its positive impact on consumers' hypermarket visit intention, because CRM is currently underresearched.

CRM is one of the CSR activities carried out by companies (Anuar \& Mohamad, 2012). CRM is the focus of this study because it is recognised as the most creative, cost-effective and popular marketing strategy (Galan Ladero et al., 2015). Varadarajan and Menon (1988) defined CRM as an action that creates and employs marketing activities through the proposal that a firm donates a designated sum of funds to a chosen social cause in exchange for revenue-providing activities through purchase of the company's products or services. The increased adoption of CRM by many organizations has mainly been due to the various benefits that companies could gain, such as improved sales and profits as well as enhanced corporate and brand image (Anuar \& Mohamad, 2011). CRM can help companies draw more consumers, escalate sales and enhance their favourable image with the public (Anghel $e t$ al., 2011).

CRM manages to bring a company and its consumers closer through their shared moral values and societal integrity (Soni \& Soni, 2013). For example, Langen et al.'s (2013) study reported that $93 \%$ of consumers purchased a CRM product because they felt that doing something good was important. Therefore, CRM can be a source of competitive advantage for companies that intend to differentiate themselves from others and attract more consumers. The present study evaluates whether CRM could be used by hypermarkets to improve their performance in terms of increased consumer visits.

\subsection{Theory of Planned Behaviour}

One of the models that is widely used to predict the intention and behaviour of consumers 
is TPB (Ajzen, 1991). TPB indicates that attitude, subjective norm and perceived behavioural control influence intention and, in turn, behaviour (Ajzen, 1985). Attitude towards a behaviour is defined as the extent to which an individual has a positive or negative perception of the behaviour. Subjective norm is defined as the perception of social pressure to perform or not perform the behaviour (Verbeke \& Vackier, 2005). Perceived behavioural control is defined as the perception of how well an individual can control the factors that support or hinder the actions required to handle a particular situation (Han et al., 2010). Intention is defined as the likelihood of a person to behave in a particular way (Fishbein \& Ajzen, 1975). Most empirical applications of TPB have explained and predicted human behaviour in various areas to understand the relationships among attitude, SN, PBC and behavioural intention, such as studies related to food choice (e.g. Lorenz et al., 2015), tourism decisions (e.g. Hsu \& Huang, 2012), online buying (e.g. Yusta et al., 2011) social entrepreneurial intention (e.g. Cavazos-Arroyo et al., 2017) and consumers' shoplifting prevention behaviour (e.g. Potdar et al., 2018). However, TPB has not been used in the context of consumers' participation intention regarding CRM.

TPB may enhance the prediction of consumers' participation intention regarding CRM and hypermarket visit intention. Ajzen (1991) stated that a person's attitude is established by behavioural beliefs, which suggests that some cognitive motivation or factors could affect attitude. In addition, research points to the fact that attitude gives the highest explained variance of intention (e.g. Lam \& Hsu, 2006; Pookulangara et al., 2011). Therefore, in this study, aside from applying the proposed determinants of TPB (i.e. attitude, $\mathrm{SN}$ and $\mathrm{PBC}$ ), the antecedents of attitude towards the CRM campaign, such as AFM, CSRI, CCI and CCF, are also explored. These four variables were chosen for this study based on a brief pilot study with 10 faculty members, asking them about their motivation to participate in CRM, from which these four variables emerged as main themes. Also, the same four factors have been consistently supported in the literature for explaining CRM intention (e.g. Moosmayer \& Fuljahn, 2013; Lii \& Lee, 2012; Deng \& Xu, 2017; Samu and Wymer, 2009). Thus, this gives a richer understanding of the factors influencing consumers' CRM participation and hypermarket visit intention. This study is similar to that of Cavazos-Arroyo et al. (2017), which extended the traditional TPB model by including the antecedents (e.g. social vision, sustainable values, financial return interests) of social entrepreneurial attitudes.

In short, despite the vast amount of empirical work on CRM, an understanding of the effects of the TPB factors on CRM participation intention and consumers' hypermarket visit intention is lacking. The present study extends TPB by taking into account the antecedents to attitude aside from the three TPB factors (attitude, SN and PBC).

\section{Theoretical framework}

\section{I Altruistic Firm Motives (AFM)}

Moosmayer and Fuljahn (2013) reported that the perceived firm motive influences consumers' assessment and attitude towards CRM and further affects consumers' decision to participate in a CRM campaign. Specifically, a profit-oriented motive is usually evaluated as unfavourable by consumers, whereas an altruistic motive is evaluated positively. Similarly, a retailers' altruistic social image may enhance the retailercustomer relationship (Potdar et al., 2018). Ellen et al. (2000) found that consumers show a more positive response to a CRM campaign when they believe that the firm's motives are intrinsically (genuine help) rather than extrinsically (profitrelated) motivated. The hypermarket's CRM campaign communication in this study is designed in such a way that "other-serving" aspects are prominent. For example, taglines such as "promote sustainable economics and empower individuals" (see Appendix I) are used on the boards. In short, when a hypermarket's motive 
is deemed to be altruistic (other-serving) by consumers, they exhibit a more positive attitude towards the CRM campaign, which leads to the development of the following hypothesis:

H1: A positive relationship exists between an altruistic firm motive and consumers' attitude towards a CRM campaign.

\subsection{Consumer-Company Identification (CCI)}

An important source of social identity is membership of diverse social groups and relationships with various organizations (Kang et al., 2015). For instance, organizational identification happens when employees' beliefs about their organization become incorporated into their self-concept, and the employees see themselves as exemplifying the organization (Azim, 2016; Cavazotte et al., 2017). This relationship can also be applied in the consumers' setting, where consumers' desire for a sense of belonging can build a socially identifying relationship with a company (Brewer, 1991). Consumers psychologically define themselves as part of the company by internalising the company's conventional norms as personal norms, leading to a favourable attitude towards that company (Curra's-Pe'rez et al., 2009). Similarly, when consumers have a high CCI with a hypermarket, they have a higher tendency to help in the hypermarket's success, and thus tend to have a positive attitude regarding the activities organized by the hypermarket, including the CRM campaign (Lii \& Lee, 2012). Therefore, the following hypothesis is presented:

H2: A positive relationship exists between consumer-company identification and consumers' attitude towards a CRM campaign.

\subsection{Perceived CSR image (CSRI)}

Lacey et al. (2015) defined perceived CSR as consumers' assessment of a company's achievements in meeting its stakeholder expectations and its societal obligations by being involved in various charitable activities. An unfavourable CSR image perceived by consumers may lead to negative outcomes for the company such as boycotting (Becker-Olsen et al., 2006), while a favourable CSR image perceived by consumers leads to a positive effect on purchase intention, recommend intention and loyalty (Deng \& Xu, 2017). According to Park et al. (2017), when consumers perceive that a company has high ethical standards, they believe that the firm is committed to its CSR initiatives. Therefore, when consumers perceive that the previous CSR activities implemented by a hypermarket reveal a favourable CSR image, they are more inclined to have a positive attitude towards the current CRM campaign. Thus, the following hypothesis is presented:

H3: A positive relationship exists between the perceived CSR image of the hypermarket and consumers' attitude towards the CRM campaign.

\subsection{Perceived Company-Cause Fit (CCF)}

A high CCF reflects an apparent relationship between a company's core business and its designated social cause. Accordingly, Van den Brink et al. (2006) asserted that a CRM campaign with a high CCF has a 5-10 times greater effect than one with a low CCF. When the company and cause seem complementary as the latter fits the company's identity, consumers perceive the company's CSR activities to be genuine (Alhouti et al., 2016). Samu and Wymer (2009) found that a higher fit led to a more favourable attitude and behavioural intention. When a CRM campaign shows a high CCF, consumers perceive that the campaign message may enhance the sustainability of the company and find helping to be reasonable. In the case of the cause used by this study, the underprivileged individuals are trained to be entrepreneurs who supply products to the hypermarkets, and increase local content variety. Therefore, consumers may 
form a favourable attitude towards the CRM campaign. The following hypothesis is derived:

H4: A positive relationship exists between company-cause fit and consumers' attitude towards a CRM campaign.

\subsection{CRM Participation Intention and Hypermarket Visit Intention}

TPB implies that intention is the most important predictor of behaviour (Arvola et al., 2008), and behavioural intention is known to be a function of attitude, SN and PBC (Ajzen, 1991). Therefore, the greater the attitude, SN and PBC, the stronger a person's intention to perform that particular behaviour is (Bamberg et al., 2003). Firstly, when an individual has a favourable attitude towards a specific behaviour, the individual's intention to engage in the behaviour is enhanced (Ajzen, 1991). For example, a significant relationship was found between the attitude of young adults towards advertising and their intention regarding advertising (Ting et al., 2015). Therefore, this study predicts that consumers with a positive attitude towards a CRM campaign are more likely to have a stronger intention to participate in it.

Secondly, Han et al. (2010) defined subjective norm as the probability of whether important referents agree or disagree with the behaviour. It was found that $\mathrm{SN}$ influenced intention to purchase through the internet (Yusta et al., 2011). In this study, when people around the individual think that a CRM campaign is a good way to help a worthy cause, then the individual's perceived social pressure to participate in the CRM campaign intensifies. Thirdly, perceived behavioural control is low when an individual has little control over executing a specific behaviour because of the lack of access to essential resources. Wu et al. (2016) found that PBC plays the most significant role in explaining senior citizens' intention in relation to physical activities in Taiwan. In this study, when consumers feel that they have full control over the decision to participate in a CRM campaign because of sufficient resources such as time and money, they are more likely to participate in the CRM campaign.

The literature implies that intention is significantly correlated with behaviour. GrahamRowe et al. (2015) pointed out that the greater a person's intention to execute a behaviour, the greater the likelihood that the behaviour would be performed. Therefore, in this study, CRM participation intention is viewed as a motivation factor in the decision to visit a hypermarket that implements CRM. Evidence shows that consumers tend to buy from a company with CRM (Langen et al., 2013). Therefore, consumers' hypermarket visit intention increases because they want to support a CRM campaign. The following hypotheses are derived:

H5: A positive relationship exists between attitude towards CRM and consumers' participation intention regarding the CRM campaign.

H6: A positive relationship exists between subjective norm and consumers' participation intention regarding the CRM campaign.

H7: A positive relationship exists between perceived behavioural control and consumers' participation intention regarding the CRM campaign.

H8: A positive relationship exists between consumers' participation intention regarding the CRM campaign and consumers' hypermarket visit intention. 


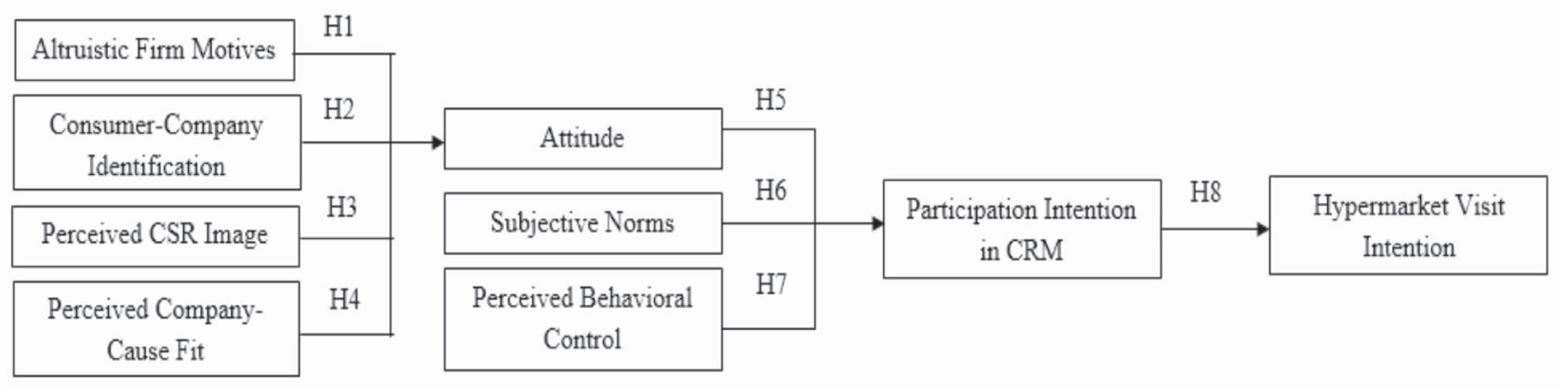

Figure 1 - Conceptual Framework

\section{Research methodology}

\section{I Data Collection and Sampling}

Data were gathered from consumers in Malaysia during the month of February in 2017 using a self-administered questionnaire method. The questionnaire was adapted from established past literature and was back-translated to Malay and Mandarin by the first author of the paper. Then, the questionnaire was back-translated into English by two other authors to create translation validity following the approach suggested by Brislin (1970). After that, the questionnaires were distributed to consumers in malls in three states of Malaysia (Selangor, Federal Territory of Kuala Lumpur \& Putrajaya, and Johor) using the mall-intercept approach. Respondents were intercepted in the malls by asking whether they would be willing to participate in a research survey and the respondents who agreed to participate were given the questionnaire to be completed on the spot. Upon completion, the respondent was given a RM20 (about USD5) cash voucher as a token of appreciation. A total of six malls were approached, three located in urban areas and three in sub-urban areas. Two malls (one urban and one sub-urban) were selected from each state. The three states (Selangor, Federal Territory of Kuala Lumpur \& Putrajaya, and Johor) were chosen for data collection because they have the highest numbers of hypermarket outlets (top three highest) (Department of Statistics Malaysia, 2011).
The respondents were asked to rank their most preferred hypermarket (most frequently visited) ranging from 1 to 5 (e.g. Giant, Tesco, AeonBig, Mydin and NSK) and were required to read a hypothetical CRM campaign based on their most preferred hypermarket (Appendix 1) before filling in the questionnaire. In other words, the respondent's most preferred hypermarket would be the hypermarket that they may identify with, as it is their most frequently visited hypermarket. Also, the social cause (supporting underprivileged individuals) in Appendix 1 was selected because the NGO's (CASE) aim was to develop or train these underprivileged individuals in entrepreneurship skills so that they could survive on their own by starting small businesses in their community. This cause is associated with the hypermarkets, where products produced by these underprivileged individuals may be future supplies of the hypermarkets.

\section{2 Respondents}

The final sample consisted of 460 consumers, $58.4 \%$ of whom were females. Most of the respondents were Malays (47\%), followed by Chinese (33\%) and Indians (18.5\%). The majority of the respondents were aged $31-40$ years old (32.4\%). Almost half had obtained a bachelor's degree $(47.8 \%)$. This is consistent with Malaysia's Ministry of Education Graduate Tracer Study 2015, where 45\% of Malaysian graduates hold a Bachelor's Degree and Diploma (The Ministry of Higher Education and Bank 
Negara Malaysia, 2017). Moreover, the results in Appendix 2 indicated no significant differences in hypermarket visit intention and CRM participation intention across the various educational groups. In addition, most of them had a monthly income of RM2000-RM4000 (USD483.27 - USD966.54) (32.4\%). This is in line with the findings of the Department of Statistics of Malaysia, which stated that the average monthly wage of Malaysians in 2017 was about RM2,880 (USD696.83) (The Star Online, 2018).

An additional analysis was performed to uncover differences in hypermarket visit intention and CRM participation intention across the various respondent profiles, such as gender, education level and monthly income. An independent sample T-test and one-way ANOVA were employed for this purpose and the results are shown in the tables of Appendix 2. There were no significant differences in hypermarket visit intention between genders, educational levels and income levels. As for CRM participation intention, no differences between genders and educational levels were found, but there was a difference between income groups. Apparently, those with a higher income (RM12000 - 16000) (USD2904-3871) were significantly more likely to participate in CRM than other income groups.

\subsection{Measures}

This study used a seven-point Likert scale (from strongly disagree to strongly agree) to measure the constructs. Table 1 provides the list of sample items and their references, where the items were adapted from. 
Table 1

\section{Sample items of measurement instrument}

\begin{tabular}{|c|c|c|c|}
\hline Construct & \multicolumn{2}{|c|}{ Sample Items } & Authors \\
\hline \multirow{2}{*}{$\begin{array}{l}\text { Altruistic Firm } \\
\text { Motives }\end{array}$} & AFM1 & Pure (Sincere) & \multirow{2}{*}{$\begin{array}{l}\text { Six items from Folse, } \\
\text { Niedrich and Grau (2010) }\end{array}$} \\
\hline & AFM2 & Unselfish & \\
\hline \multirow{2}{*}{$\begin{array}{l}\text { Consumer- } \\
\text { Company } \\
\text { Identification }\end{array}$} & CCI1 & This hypermarket's principle is similar to my values. & \multirow{2}{*}{$\begin{array}{l}\text { Six items from Mael and } \\
\text { Ashforth (1992)and Wu } \\
\text { and Tsai (2008) }\end{array}$} \\
\hline & $\mathrm{CCI} 2$ & $\begin{array}{l}\text { When someone praises this hypermarket, it feels like a personal } \\
\text { compliment. }\end{array}$ & \\
\hline \multirow[t]{2}{*}{$\begin{array}{l}\text { Perceived CSR } \\
\text { Image }\end{array}$} & CSRI1 & $\begin{array}{l}\text { I think this hypermarket has a legitimate (genuine/sincere) interest in } \\
\text { this cause. }\end{array}$ & \multirow[t]{2}{*}{$\begin{array}{l}\text { Five items from Folse et al. } \\
(2010)\end{array}$} \\
\hline & CSRI2 & This hypermarket is socially responsible. & \\
\hline \multirow[t]{2}{*}{$\begin{array}{l}\text { Perceived } \\
\text { Company-Cause Fit }\end{array}$} & CCF1 & $\begin{array}{l}\text { The "supporting underprivileged individuals" cause implemented by } \\
\text { this hypermarket fits with the nature of its business. }\end{array}$ & \multirow[t]{2}{*}{$\begin{array}{l}\text { Three items from Ellen, } \\
\text { Webb and Mohr (2006) }\end{array}$} \\
\hline & CCF2 & $\begin{array}{l}\text { The "supporting underprivileged individuals" cause implemented by } \\
\text { this hypermarket is relevant to its business. }\end{array}$ & \\
\hline \multirow[t]{2}{*}{ Attitude } & ATT1 & $\begin{array}{l}\text { I like the idea of buying products from a hypermarket which donates } \\
\text { part of its profits to a social cause or NGO. }\end{array}$ & \multirow[t]{2}{*}{$\begin{array}{l}\text { Four items from Kropp, } \\
\text { Holden and Lavack (1999) }\end{array}$} \\
\hline & ATT2 & $\begin{array}{l}\text { I am willing to pay more for a product from a hypermarket if the } \\
\text { hypermarket is donating part of the profits to a social cause. }\end{array}$ & \\
\hline \multirow[t]{2}{*}{ Subjective Norm } & SN1 & $\begin{array}{l}\text { The trend of purchasing products from a hypermarket that supports a } \\
\text { social cause among people around me is increasing. }\end{array}$ & \multirow{2}{*}{$\begin{array}{l}\text { Four items from Al-Swidi, } \\
\text { Mohammed Rafiul Huque, } \\
\text { Haroon Hafeez and Noor } \\
\text { Mohd Shariff (2014) }\end{array}$} \\
\hline & SN2 & $\begin{array}{l}\text { People around me generally believe that it is a good idea to purchase } \\
\text { products from a hypermarket that supports a social cause. }\end{array}$ & \\
\hline \multirow[t]{2}{*}{$\begin{array}{l}\text { Perceived } \\
\text { Behavioural Control }\end{array}$} & PBC1 & $\begin{array}{l}\text { I can make the decision independently to purchase products from a } \\
\text { hypermarket that supports a social cause. }\end{array}$ & \multirow[t]{2}{*}{$\begin{array}{l}\text { Five items from Al-Swidi et } \\
\text { al. (2014) }\end{array}$} \\
\hline & $\mathrm{PBC} 2$ & $\begin{array}{l}\text { I have the financial capability to purchase products from a } \\
\text { hypermarket that supports a social cause. }\end{array}$ & \\
\hline \multirow[t]{2}{*}{$\begin{array}{l}\text { CRM Participation } \\
\text { Intention }\end{array}$} & CRMPI1 & $\begin{array}{l}\text { I think this hypermarket's campaign for "supporting underprivileged } \\
\text { individuals' is a good idea. }\end{array}$ & \multirow[t]{2}{*}{$\begin{array}{l}\text { Four items from Folse et al. } \\
(2010)\end{array}$} \\
\hline & CRMPI2 & $\begin{array}{l}\text { I would be willing to participate in this hypermarket's campaign } \\
\text { for "supporting underprivileged individuals" by buying most of my } \\
\text { groceries from this hypermarket. }\end{array}$ & \\
\hline \multirow[t]{2}{*}{$\begin{array}{l}\text { Hypermarket Visit } \\
\text { Intention }\end{array}$} & HVI1 & $\begin{array}{l}\text { I would recommend this hypermarket that "supports underprivileged } \\
\text { individuals" to someone who seeks my advice. }\end{array}$ & \multirow{2}{*}{$\begin{array}{l}\text { Four items from Grewal, } \\
\text { Baker and Voss (2003), } \\
\text { Olorunniwo, Hsu and Udo } \\
(2006)\end{array}$} \\
\hline & HVI2 & $\begin{array}{l}\text { I would say positive things about this hypermarket that "supports } \\
\text { underprivileged individuals" to other people. }\end{array}$ & \\
\hline
\end{tabular}

\subsection{Data Analysis}

To analyse the research model, this study employed the partial least squares (PLS) - structural equation modelling (SEM) analysis technique using SMARTPLS 3.2.3 (Ringle et al., 2015). As recommended by Anderson and Gerbing (1988), this study applied the twostage analytical procedure: measurement model (validity and reliability of the measures) and structural model (hypothesised relationship testing) (Hair et al., 2014). In the PLS-SEM, the model evaluations used the $\mathrm{R}$-squared values for evaluating endogenous variables and effect size, while significance levels and t-values were used to evaluate the structural path coefficients (Fornell \& Cha, 1994). Moreover, the estimations of standard errors and t-values were derived by performing a bootstrapping resampling technique with 1,000 resamples (Chin, 1998). 


\section{Results and analysis}

\section{I Measurement Model Validation}

This study assessed the measurement model by examining two types of validity, namely convergent validity and discriminant validity. Convergent validity of the measurement model is generally verified by determining the loading, Cronbach's alpha, composite reliability and average variance extracted (AVE) (Gholami et al., 2013). As shown in Table 2 , the indicators' outer loadings for all items exceeded the recommended value of 0.5 (Hair et al., 2010). The Cronbach's alpha values of all constructs were above 0.7, which indicates internal consistency (Nunnally \& Bernstein, 1994). The composite reliability values had a range of $0.887-0.952$, which was greater than the threshold level of 0.7 (Hair et al., 2010). The AVE had a range of 0.628-0.831, which was greater than the cut-off value of 0.5 (Hair et al., 2010).

After that, discriminant validity was then examined by following the Fornell and Larcker (1981) criterion. As shown in Table 3, the square root of the AVE was denoted by the bold values on the diagonal. These values exceeded the offdiagonal values of the corresponding row and column, thus demonstrating that the measures were discriminant. In conclusion, both convergent and discriminant validity were established. Additionally, the standardised root mean square residual (SRMR) was tested to examine the model fit. The threshold value of below 0.08 is considered a good fit (Hu \& Bentler, 1999). The model in the current study obtained an SRMR value of 0.058 , which indicated a good fit. 
Table 2

Measurement model: loadings, construct reliability and convergent validity

\begin{tabular}{|c|c|c|c|c|}
\hline Construct/Indicator & Loading & $\begin{array}{c}\text { Composite reliability } \\
\text { (CR) }\end{array}$ & Cronbach's alpha & $\begin{array}{c}\text { Average variance } \\
\text { extracted (AVE) }\end{array}$ \\
\hline Altruistic Firm Motives & & 0.914 & 0.888 & 0.640 \\
\hline AFM1 & 0.793 & & & \\
\hline AFM2 & 0.814 & & & \\
\hline AFM3 & 0.851 & & & \\
\hline AFM4 & 0.787 & & & \\
\hline AFM5 & 0.773 & & & \\
\hline AFM6 & 0.777 & & & \\
\hline Consumer-Company Identification & & 0.910 & 0.884 & 0.628 \\
\hline CCI1 & 0.728 & & & \\
\hline $\mathrm{CCI} 2$ & 0.829 & & & \\
\hline $\mathrm{CCI} 3$ & 0.792 & & & \\
\hline CCI4 & 0.817 & & & \\
\hline $\mathrm{CCI} 5$ & 0.825 & & & \\
\hline CCI6 & 0.760 & & & \\
\hline Perceived CSR Image & & 0.925 & 0.898 & 0.712 \\
\hline CSRI1 & 0.834 & & & \\
\hline CSRI2 & 0.868 & & & \\
\hline CSRI3 & 0.875 & & & \\
\hline CSRI4 & 0.866 & & & \\
\hline CSRI5 & 0.770 & & & \\
\hline Perceived Company-Cause Fit & & 0.921 & 0.871 & 0.795 \\
\hline CCF1 & 0.890 & & & \\
\hline $\mathrm{CCF} 2$ & 0.905 & & & \\
\hline CCF3 & 0.880 & & & \\
\hline Attitude & & 0.887 & 0.829 & 0.665 \\
\hline ATT1 & 0.801 & & & \\
\hline ATT2 & 0.702 & & & \\
\hline ATT3 & 0.897 & & & \\
\hline ATT4 & 0.850 & & & \\
\hline Subjective Norm & & 0.926 & 0.893 & 0.757 \\
\hline SN1 & 0.843 & & & \\
\hline SN2 & 0.872 & & & \\
\hline SN3 & 0.893 & & & \\
\hline SN4 & 0.870 & & & \\
\hline Perceived Behavioural Control & & 0.900 & 0.862 & 0.644 \\
\hline $\mathrm{PBC} 1$ & 0.834 & & & \\
\hline PBC2 & 0.849 & & & \\
\hline PBC3 & 0.845 & & & \\
\hline PBC4 & 0.771 & & & \\
\hline PBC5 & 0.704 & & & \\
\hline CRM Participation Intention & & 0.924 & 0.889 & 0.753 \\
\hline CRMPI1 & 0.792 & & & \\
\hline CRMPI2 & 0.877 & & & \\
\hline CRMPI3 & 0.911 & & & \\
\hline CRMPI4 & 0.885 & & & \\
\hline Hypermarket Visit Intention & & 0.952 & 0.932 & 0.831 \\
\hline HVI1 & 0.906 & & & \\
\hline HVI2 & 0.908 & & & \\
\hline HVI3 & 0.925 & & & \\
\hline HVI4 & 0.907 & & & \\
\hline
\end{tabular}


Table 3

Discriminant validity of the measurement model: Fornell and Larcker (1981)

\begin{tabular}{|c|c|c|c|c|c|c|c|c|c|}
\hline & ATT & CRMPI & CSRI & CCF & CCI & AFM & PBC & SN & HVI \\
\hline ATT & 0,816 & & & & & & & & \\
\hline CRMPI & 0,696 & 0,868 & & & & & & & \\
\hline CSRI & 0,559 & 0,549 & 0,844 & & & & & & \\
\hline CCF & 0,522 & 0,531 & 0,632 & 0,892 & & & & & \\
\hline CCI & 0,457 & 0,488 & 0,591 & 0,607 & 0,793 & & & & \\
\hline AFM & 0,493 & 0,498 & 0,777 & 0,573 & 0,529 & 0,800 & & & \\
\hline PBC & 0,672 & 0,588 & 0,517 & 0,493 & 0,488 & 0,448 & 0,802 & & \\
\hline SN & 0,632 & 0,521 & 0,516 & 0,553 & 0,582 & 0,456 & 0,611 & 0,870 & \\
\hline HVI & 0,682 & 0,641 & 0,469 & 0,441 & 0,376 & 0,422 & 0,586 & 0,484 & 0,912 \\
\hline
\end{tabular}

Note: Diagonals represent the square root of the AVE, and the off-diagonals represent the correlations.

\section{2 Descriptive Statistics (Mean, Standard Deviation, Skewness and Kurtosis)}

Table 4 shows the descriptive statistics and normality test of the constructs. Based on the result, the CRM factors (Altruistic Firm Motives, Consumer-Company Identification, Perceived Corporate Social Responsibility Image, and Perceived Company-Cause Fit) that would motivate consumers to participate in a CRM campaign recorded mean scores above 4 on a 7 -point Likert scale (where 1 = Strongly Disagree and $7=$ Strongly Agree). In other words, the respondents agreed that their preferred hypermarket exhibited altruistic firm motives, consumer-company identification, a perceived corporate social responsibility image, and a perceived company-cause fit.

Similarly to the theory of planned behaviour elements (attitude, subjective norms and perceived behavioural control), the respondents generally showed that attitude towards CRM $(M=5.302)$, subjective norms $(M=5.019)$, and perceived behavioural control $(M=5.175)$ were high in the context of the hypermarket CRM on a 7-point Likert scale (where 1 = Strongly Disagree and 7 = Strongly Agree). The respondents also showed that they have strong intentions to participate in a CRM campaign $(M=5.347)$. Table 4 also shows that the respondents have strong intentions to visit a hypermarket that implements a CRM campaign $(M=5.390)$.

Hair et al. (2014) asserted that absolute skewness and/or kurtosis values of within $+/-1$ are indicative of highly normal data. As presented in Table 4, all the constructs were within the acceptable skewness range except two constructs (perceived behavioural control and hypermarket visit intention) which did not meet the acceptable kurtosis range. However, the non-normal distribution problem is not an issue with PLSSEM as it statistically provides a very resilient model of estimations with normal and extremely non-normal data (i.e., skewness and/or kurtosis) distributional properties (Reinartz, Haenlein \& Henseler, 2009) by employing the bootstrapping technique. 
Table 4

Descriptive Statistics (Mean, Standard Deviation, Skewness and Kurtosis)

\begin{tabular}{|c|c|c|c|c|c|c|c|}
\hline \multirow[b]{2}{*}{ No. } & \multirow[b]{2}{*}{ Constructs } & \multirow[b]{2}{*}{ Mean } & \multirow[b]{2}{*}{$\begin{array}{l}\text { Standard } \\
\text { Deviation }\end{array}$} & \multicolumn{2}{|c|}{ Skewness } & \multicolumn{2}{|c|}{ Kurtosis } \\
\hline & & & & Statistic & Std. Error & Statistic & Std. Error \\
\hline 1 & Altruistic Firm Motives & 5.186 & 0.863 & -0.136 & 0.114 & -0.371 & 0.227 \\
\hline 2 & Consumer-Company Identification & 4.698 & 0.991 & -0.563 & 0.114 & 0.504 & 0.227 \\
\hline 3 & Perceived CSR Image & 5.110 & 0.945 & -0.439 & 0.114 & 0.352 & 0.227 \\
\hline 4 & Perceived Company-Cause Fit & 5.011 & 0.922 & -0.078 & 0.114 & 0.042 & 0.227 \\
\hline 5 & Attitude & 5.302 & 0.932 & -0.442 & 0.114 & 0.612 & 0.227 \\
\hline 6 & Subjective Norm & 5.019 & 0.983 & -0.415 & 0.114 & 0.253 & 0.227 \\
\hline 7 & Perceived Behavioural Control & 5.175 & 0.919 & -0.624 & 0.114 & 1.105 & 0.227 \\
\hline 8 & CRM Participation Intention & 5.347 & 0.960 & -0.622 & 0.114 & 0.703 & 0.227 \\
\hline 9 & Hypermarket Visit Intention & 5.390 & 0.952 & -0.632 & 0.114 & 1.308 & 0.227 \\
\hline
\end{tabular}

\subsection{Structural Model Assessment}

Hypothesis testing in this study was performed by evaluating the structural model. The coefficient of determination $\left(\mathrm{R}^{2}\right)$, the beta and the corresponding $\mathrm{t}$-values were assessed by running a bootstrapping procedure with 1,000 resamples (Hair et al., 2014). Aside from these basic measures, predictive relevance $\left(\mathrm{Q}^{2}\right)$ and effect sizes $\left(\mathrm{f}^{2}\right)$ were also reported (Hair et al., 2014). As shown in Table 5 , six out of the eight hypotheses were supported. Firstly, CCI $(\beta=0.103$, t-value $>1.645)$, CSRI $(\beta=0.288, \mathrm{t}$-value $>1.645)$ and CCF $(\beta=0.229, \mathrm{t}$-value $>1.645)$ were all positively related to attitude towards CRM. Thus, $\mathrm{H} 2, \mathrm{H} 3$ and $\mathrm{H} 4$ were supported but not $\mathrm{H} 1$ (AFM; $\beta=0.083$, t-value < 1.645). In total, CCI, CSRI and CCF explained $36.9 \%$ of the variance in attitude. Secondly, attitude $(\beta=0.519$, t-value $>1.645)$ and PBC $(\beta=0.194$, $\mathrm{t}$-value $>1.645)$ were positively related to CRM participation intention. Therefore, $\mathrm{H} 5$ and $\mathrm{H} 7$ were supported but not H6 (SN; $\beta=0.075$, t-value $<1.645$ ). Overall, attitude and PBC explained $51.4 \%$ of the variance in CRM participation intention. Lastly, CRM participation intention $(\beta=0.641$, $t$-value $>1.645)$ was positively related to hypermarket visit intention, explaining $41 \%$ of the variance in hypermarket visit intention. Thus, $\mathrm{H} 8$ was supported. The $\mathrm{R}^{2}$ values all exceeded the 0.35 value, which implies a substantial model, as suggested by Cohen (1988).

The effect sizes $\left(f^{2}\right)$ were also assessed. Cohen's (1988) guideline was used to measure the degree of effect sizes, which are trivial $(<0.02)$, small (0.02), medium (0.15) and large (0.35). As shown in Table 5, six relationships showed substantive effects (i.e. one trivial effect size, three small effect sizes, one medium effect size and one large effect size). Using a blindfolding procedure, this study examined the predictive relevance of the model. Table 5 shows the three $\mathrm{Q}^{2}$ values for attitude $\left(Q^{2}=0.241\right)$, CRM participation intention $\left(Q^{2}=0.382\right)$ and hypermarket visit intention $\left(Q^{2}=0.339\right)$. All values were above 0 , which implies that the model has sufficient predictive relevance (Hair et al., 2014; Fornell \& Cha, 1994). 
Table 5

Results of the structural model analysis (hypotheses testing)

\begin{tabular}{|c|c|c|c|c|c|c|c|c|}
\hline Hypothesis & Relationships & $\begin{array}{c}\text { Standard } \\
\text { Beta }\end{array}$ & $\begin{array}{l}\text { Standard } \\
\text { Deviation }\end{array}$ & t-value & Decision & $\mathbf{R} 2$ & f 2 & Q2 \\
\hline $\mathrm{H} 1$ & AFM $\Rightarrow$ ATT & 0,083 & 0,072 & 1,156 & Not Supported & 0,369 & 0,004 & 0,241 \\
\hline $\mathrm{H} 2$ & $\mathrm{CCI} \Rightarrow \mathrm{ATT}$ & 0,103 & 0,058 & $1,773^{*}$ & Supported & & 0,009 & \\
\hline $\mathrm{H} 3$ & CSRI $\Rightarrow$ ATT & 0,288 & 0,075 & $3,868^{* *}$ & Supported & & 0,043 & \\
\hline $\mathrm{H} 4$ & $\mathrm{CCF} \Rightarrow \mathrm{ATT}$ & 0,229 & 0,063 & $3,661^{* *}$ & Supported & & 0,042 & \\
\hline $\mathrm{H} 5$ & ATT $\Rightarrow$ CRMPI & 0,519 & 0,053 & $9,827^{* *}$ & Supported & 0,514 & 0,261 & 0,382 \\
\hline H6 & $\mathrm{SN} \Rightarrow \mathrm{CRMPI}$ & 0,075 & 0,059 & 1,269 & Not Supported & & 0,006 & \\
\hline $\mathrm{H} 7$ & $\mathrm{PBC} \Rightarrow \mathrm{CRMPI}$ & 0,194 & 0,059 & $3,281^{* *}$ & Supported & & 0,038 & \\
\hline $\mathrm{H} 8$ & CRMPI $\Rightarrow$ HVI & 0,641 & 0,043 & $14,847^{* *}$ & Supported & 0,410 & 0,696 & 0,339 \\
\hline
\end{tabular}

Note: ${ }^{*} p<0.05 ;{ }^{* *} p<0.01$

AFM Altruistic Firm Motives, CCI Consumer-Company Identification, CSRI Perceived CSR Image, CCF Perceived Company-Cause Fit, ATT Attitude towards CRM, SN Subjective Norm, PBC Perceived Behavioural Control, CRMPI Cause-Related Marketing Participation Intention, HVI Hypermarket Visit Intention

\section{Discussion}

Grounded in the theory of planned behaviour, this study determined the factors affecting CRM participation and hypermarket visit intention of consumers in Malaysia. As attitude plays the most significant role in explaining intention (e.g. Luna et al., 2017; Ting et al., 2015), this study identified the antecedents to attitude. The result shows that CCI, CSRI and CCF significantly affect attitude towards CRM participation intention. This finding is in accordance with those of Lii and Lee (2012), Deng and Xu (2017) and Van den Brink et al. (2006). However, this study did not find support for the effect of AFM on CRM participation intention. This outcome could be due to the fact that Malaysian consumers find it difficult to evaluate the motives of firms. Consumers are confused about the motives of hypermarkets in Malaysia as Malaysian government agencies (e.g. Ministry of Domestic Trade and Consumer Affairs) have been actively driving campaigns where hypermarkets are expected to co-organize. Some of these projects, which help SMEs' products get placed in hypermarkets. Consumers may think that hypermarkets participate in these governmentdriven campaigns due to compliance obligations.
Thus, hypermarket motives may be masked by compliance issues, which make it difficult for consumers to assess the altruistic levels of hypermarkets when organizing CRM campaigns. Furthermore, the insignificant effect of altruistic firm motives on attitude could be due to the fact that the impact of altruistic firm motives on attitude is overlapping with perceived corporate social responsibility. Altruistic firm motives and perceived corporate social responsibility has a correlation coefficient of 0.777 (Table 3), which indicates that these two dimensions are very similar in the eyes of respondents.

Various fields of research have used TPB to predict behavioural intention. Most of them have found attitude to have the strongest effect (e.g. Hsu et al., 2017; Luna et al., 2017). The same result is found in this study, in which attitude has the strongest effect on intention relative to $\mathrm{SN}$ and PBC. The power of attitude is prominent and most likely due to the relatively new introduction of CRM in hypermarkets, which usually arouse consumers' curiosity and are prone to acceptance. It is also probably because of the good cause that the hypermarket is involved in, which gives a sense of social responsibility fulfilment to consumers and an impression that the hypermarket is playing a good corporate citizen role for society. 
However, SN does not significantly predict intention. This result may be explained by the majority of younger respondents in the study (32.4\% 31-40-year olds and 24.1\% 26-30-year olds), who are less likely to accept others' opinions on less substantial decisions like hypermarket choice. The findings in this study imply that the readiness of consumers in CRM participation is primarily driven by their perception of and belief in the CRM campaign (attitude) as well as their ability and capacity to participate in a CRM campaign (perceived behavioural control).

When consumers feel that purchasing products from a hypermarket while donating to a worthy cause at the same time is a good idea, they have a favourable attitude towards the CRM campaign, and those not influenced by their social circle (i.e. insignificant relationship between subjective norms and CRM participation intention) will be more likely to join the campaign. Furthermore, this study also reveals that CRM participation intention has a significant and positive influence on hypermarket visit intention. This result is consistent with that of Bamberg et al. (2003), which indicated that when consumers have the intention to participate in a CRM campaign, they are more willing to visit a hypermarket that runs one.

\section{I Theoretical Implications}

This study makes several contributions to the existing theoretical knowledge. Firstly, it extends the use of TPB popularised by Ajzen (1991) by adding antecedents to attitude (i.e. AFM, CCI, CSRI and CCF) to assess their influence on CRM participation intention and hypermarket visit intention. Specifically, attitude and $\mathrm{PBC}$ are found to significantly influence CRM participation intention. However, unlike in Cavazos-Arroyo et al. (2017) and Luna et al. (2017), SN in this study is found to be insignificant, which implies that CRM participation intention is not influenced by the anticipation or agreement by specific important people. Although TPB has been widely applied in various fields of study (e.g. Watanabe et al., 2015; Wu et al., 2016), TPB is scarcely used in the context of consumers' participation intention regarding CRM. Therefore, this study shows how TPB can be used as a theoretical foundation to enhance the study of CRM participation intention.

Secondly, this study adds to the existing CRM literature by providing evidence that CCI (Lii \& Lee, 2012), CSRI (Deng $\&$ Xu, 2017) and CCF (Van den Brink et al., 2006) significantly affect attitude towards CRM participation intention. This finding indicates that these factors can be used to influence consumers' perception of CRM, providing evidence on these factors' applicability in the hypermarket context involving the novel cause of supporting underprivileged individuals. Finally, this study indicates that CRM can help increase consumers' hypermarket visit intention and shows how CRM can be used as a marketing strategy to enhance visit intention in the hypermarket context.

\subsection{Managerial Implications}

Overall, the findings of this study provide suggestions to the management of hypermarkets to increase consumers' visit intention. Aside from possessing a strong retail marketing mix, hypermarkets that adopt a CRM campaign may draw in more consumers. The results indicate that variables such as CCI, CSRI and CCF play significant roles in influencing attitude towards CRM. In addition, attitude towards CRM participation has a greater effect size than $\mathrm{SN}$ and PBC. Therefore, efforts should be made in improving consumers' attitude towards the CRM campaign. Attitude towards CRM can be improved if hypermarkets portray a positive CSR image, support a social cause that is consistent with their core business, products or brand image and when the consumer can associate with the hypermarket's values.

To improve CSR image, hypermarkets can engage in more CSR initiatives that are genuine and visible to consumers. For example, they 
can engage in broader CSR initiatives targeting different salient stakeholders, such as employees, consumers and the local community. CSR for employees can be conducted by providing a quality working environment or by improving the quality of life of employees. CSR for consumers can be conducted by providing free transportation to older people for grocery shopping or by offering priority check-out lanes for senior citizens. CSR for the local community can be conducted by giving out basic necessities to the homeless, orphanages or old folks' homes and by planning occasional cleaning activities in the parks used by local residents.

To build consumers' ability and capability in participating in a CRM campaign, hypermarkets can apply CRM to all their products. For example, all purchased products could enable consumers to participate in CRM, regardless of the product being priced lower or higher and produced locally or abroad. That way, consumers are spared the hassle of finding products that are tied to the CRM campaign. Finally, hypermarkets can identify a social cause that is aligned with their core business or core values by talking to all nongovernment organizations (NGOs) operating within the vicinity. Supporting a local cause (NGO from the vicinity) may be more appealing than a non-local cause (La Ferle et al., 2013). In short, to increase consumers' intention to visit a hypermarket, the manager may want to organize a CRM campaign that appeals to them.

\subsection{Limitation and Directions for Future Research}

This study has several limitations, which readily provide avenues for future research. Firstly, this study's explanatory power for CRM attitude is $37 \%$, which indicates a $63 \%$ variance that is not explained. That is, some important factors are not included in the framework. Future studies could consider the factors that can improve the attractiveness of the CRM campaign. Examples of these factors are CRM campaign duration (Cui et al., 2003), donation proximity (Zhu et al., 2017) and type of social cause supported (Lafferty \& Edmondson, 2014). Secondly, the consumers' hypermarket visit intention explanatory power was $41 \%$, which shows that a $59 \%$ variance was not explained. Thus, future research could contemplate including additional factors into the model that may also influence consumers' hypermarket visit intention, such as advertising (Anselmsson, 2006), location (Pan \& Zinkhan, 2006) and price (Jin \& Kim, 2003).

Thirdly, the insignificant effect of altruistic firm motives on attitude might be due to the fact that the impact of altruistic firm motives on attitude is overlapping with perceived corporate social responsibility (Table 3 ), which indicates that these two dimensions are very similar. Thus, future studies should consider including either one of these variables and should not include both because a high correlation between the two variables may nullify the explanatory power of one of them due to redundancy.

Fourthly, this study relies solely on the self-reported responses of the respondents on their CRM participation and hypermarket visit intention. Consumers usually speak positively about ethical issues but do not essentially follow through with the purchases they speak of (Cui et al., 2003). Therefore, the data may not truly reflect their behaviour. Future research is suggested to verify the relationship between CRM participation and hypermarket visit intention using the observation method based on actual behavioural data. Besides that, the experimental research method may also be employed to use a control group to compare against the experimental group. Fifthly, as the sample of this study is collected from Malaysia only, generalisability to other countries may be limited because of cultural differences in consumer behaviour. Future research can consider comparing the findings of this study with those from other countries to make a cross-cultural comparison. Lastly, the responses from respondents might have some degree of bias as social desirability was not measured and not detectable in this study. Hence, future studies 
could consider incorporating social desirability measurements in the questionnaire to measure consumers' social desirability responses.

\section{Conclusion}

When consumers visit a hypermarket to purchase their daily groceries, they can decide to buy from a hypermarket that enables them to simultaneously contribute to a social cause. The empirical findings of this study show that hypermarkets that implement a CRM campaign attract more visits. Figure 2 presents the final research model of this study. This outcome suggests that the use of CRM can enhance consumers' intention to visit the hypermarket. Moreover, attitude towards the CRM campaign and PBC significantly affect consumers' intention to participate in the CRM. Therefore, CRM participation intention can be improved if consumers are convinced of the CRM benefits and if the hypermarket makes it easy for consumers to participate in the CRM campaign. Factors such as CSRI, CCI and CCF affect consumers' attitude towards CRM. Therefore, these factors should be considered by hypermarkets before and during designing a CRM campaign.

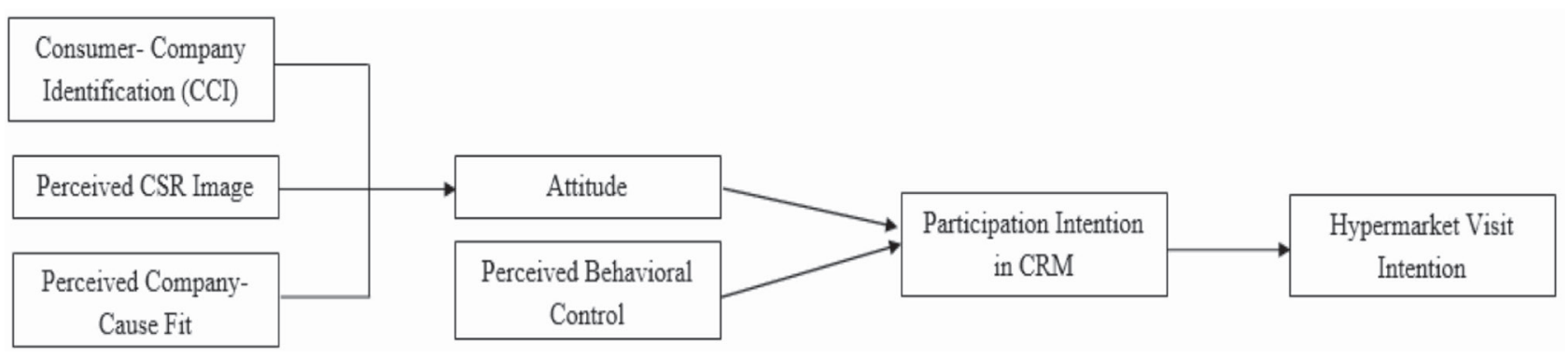

Figure 2 - Final Research Model 


\section{Appendix 1 - Hypothetical CRM campaign}

\section{"Your Preferred Hypermarket"}

"For a better economy, a better country, for us, for our children and the generations to come"
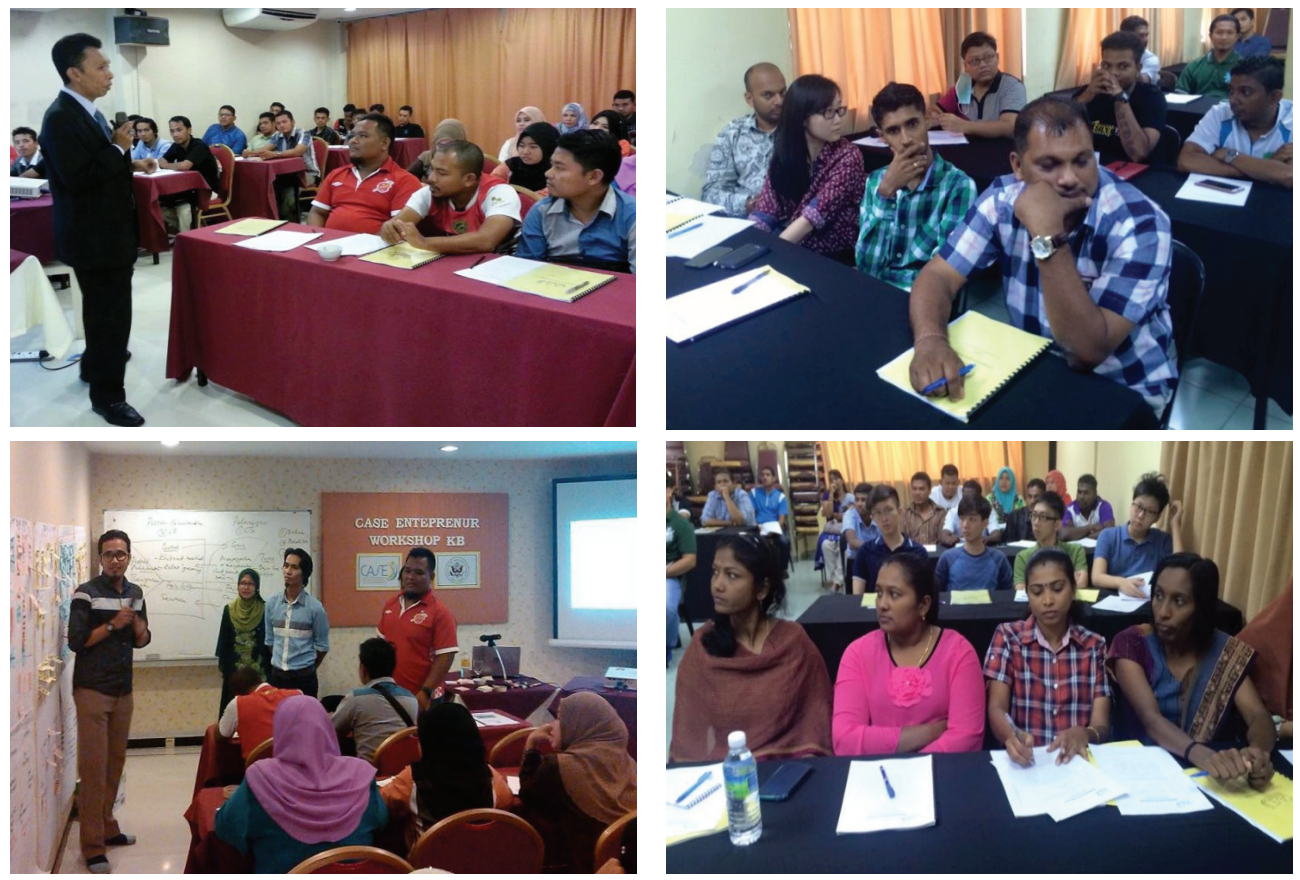

Over the next 10 years, $1 \%$ of any products' sales from "your preferred hypermarket" will be donated to CASE to aid the underprivileged individuals (e.g. single mothers, school dropouts and individuals with inadequacy of resources).

"Your Preferred Hypermarket" has established a long term collaboration with CASE to help create alternative sustainable economic successes and empow er individuals from the poverty ridden areas in Malaysia.

"Your Preferred Hypermarke" believesthat social entrepreneurship providesan alternatemodefor these underprivileged individualsto be part of the cantry sgrouth and at the sametime provideimovative, sustainablesolutions to the deep-rooted social issuesand problems that plaguetheseindividualsand their commuities

\section{InCollaboraion with}

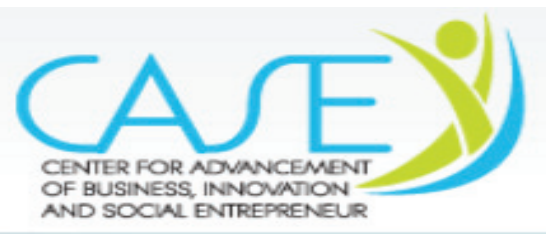

Disclaimer: The images and information on this advertisement are presented solely for academic research study. It does not reflect the brand and product in real-world. 


\section{Appendix 2-Independent T-Test on Gender, ANOVA on Highest Education Level and Monthly Income}

Table 6

Independent T-Test on Gender

\begin{tabular}{lcccccc}
\hline & \multicolumn{2}{c}{ Levene's Test for Equality of Variance } & & \\
\hline & & F & Sig. & t & df & Sig. (2-tailed) \\
\hline $\begin{array}{l}\text { Hypermarket Visit } \\
\text { Intention }\end{array}$ & Equal Variance Assumed & 0.653 & 0.419 & 0.548 & 456 & 0.584 \\
& Equal Variance not Assumed & & & 0.541 & 389.006 & 0.589 \\
$\begin{array}{l}\text { CRM Participation } \\
\text { Intention }\end{array}$ & Equal Variance Assumed & 0.857 & 0.355 & -0.236 & 456 & 0.814 \\
& Equal Variance not Assumed & & & -0.233 & 391.751 & 0.816 \\
\hline
\end{tabular}

Table 7

Results of ANOVA between Hypermarket Visit Intention, CRM Participation Intention and Education Level

\begin{tabular}{|c|c|c|c|c|c|c|}
\hline & Groups & $\mathbf{n}$ & Mean & SD & $\mathbf{F}$ & Sig. \\
\hline \multirow[t]{4}{*}{ Hypermarket Visit Intention } & SPM or lower & 118 & 5.218 & 0.944 & 2.312 & 0.075 \\
\hline & Diploma & 81 & 5.324 & 1.075 & & \\
\hline & Bachelor Degree & 220 & 5.488 & 0.904 & & \\
\hline & $\begin{array}{c}\text { Master Degree and } \\
\text { above }\end{array}$ & 41 & 5.481 & 0.931 & & \\
\hline \multirow[t]{4}{*}{ CRM Participation Intention } & SPM or lower & 118 & 5.389 & 0.953 & 1.135 & 0.335 \\
\hline & Diploma & 81 & 5.286 & 1.015 & & \\
\hline & Bachelor Degree & 220 & 5.281 & 0.991 & & \\
\hline & $\begin{array}{c}\text { Master Degree and } \\
\text { above }\end{array}$ & 41 & 5.427 & 0.930 & & \\
\hline
\end{tabular}

Table 8

Results of ANOVA between Hypermarket Visit Intention, CRM Participation Intention and Monthly Income

\begin{tabular}{|c|c|c|c|c|c|c|}
\hline & Groups & $\mathbf{n}$ & Mean & SD & $\mathbf{F}$ & Sig. \\
\hline \multirow{9}{*}{$\begin{array}{l}\text { Hypermarket Visit } \\
\text { Intention }\end{array}$} & Below RM2000 & 48 & 5.396 & 1.041 & 1.009 & 0.428 \\
\hline & RM2000 - RM4000 & 149 & 5.270 & 0.991 & & \\
\hline & RM4001 - RM6000 & 130 & 5.387 & 0.971 & & \\
\hline & RM6001 - RM8000 & 55 & 5.423 & 0.863 & & \\
\hline & RM8001 - RM10000 & 30 & 5.431 & 0.945 & & \\
\hline & RM10001 - RM12000 & 20 & 5.842 & 0.737 & & \\
\hline & RM12001 - RM14000 & 9 & 5.563 & 0.788 & & \\
\hline & RM14001 - RM16000 & 7 & 5.625 & 0.542 & & \\
\hline & RM16001 or above & 12 & 5.636 & 0.918 & & \\
\hline \multirow{9}{*}{$\begin{array}{l}\text { CRM Participation } \\
\text { Intention }\end{array}$} & Below RM2000 & 48 & 5.388 & 0.956 & 2.400 & 0.015 \\
\hline & RM2000 - RM4000 & 149 & 5.578 & 1.006 & & \\
\hline & RM4001 - RM6000 & 130 & 5.237 & 1.000 & & \\
\hline & RM6001 - RM8000 & 55 & 5.342 & 0.933 & & \\
\hline & RM8001 - RM10000 & 30 & 5.177 & 0.980 & & \\
\hline & RM10001 - RM12000 & 20 & 5.3276 & 0.68499 & & \\
\hline & RM12001 - RM14000 & 9 & 5.8816 & 0.91806 & & \\
\hline & RM14001 - RM16000 & 7 & 6.1563 & 0.46170 & & \\
\hline & RM16001 or above & 12 & 5.4167 & 0.87560 & & \\
\hline
\end{tabular}




\section{Appendix 3 - Questionnaire}

\section{Part I - Hypermarket Preferences}

Please rank your hypermarket preferences from 1 to 5 for the following hypermarkets (1 - Most Preferable, 5 - Least Preferable).
$\square \quad$ Giant
$\square \quad$ Aeon Big
NSK
Tesco
Mydin

Assuming that "Your Preferred Hypermarket" (Part I) would like to implement a campaign that supports underprivileged individuals, please read the details carefully (APPENDIX 1) and answer the questions in Part II.

\section{Part II - Cause-Related Marketing Campaign (Please refer to Appendix 1 Advertisement Board)}

\begin{tabular}{|c|c|c|c|c|c|c|}
\hline $\begin{array}{c}\text { Strongly } \\
\text { Disagree (SD) }\end{array}$ & Disagree & $\begin{array}{c}\text { Somewhat } \\
\text { Disagree }\end{array}$ & Neutral (N) & Somewhat Agree & Agree & Strongly Agree (SA) \\
\hline 1 & 2 & 3 & 4 & 5 & 6 & 7 \\
\hline
\end{tabular}

A: Altruistic Firm Motives

Based on the advertisement/campaign (Appendix 1), how would you describe "Your Preferred Hypermarket's" MOTIVES for getting involved in the cause of "supporting underprivileged individuals"? Please circle only one number.

\begin{tabular}{|c|c|c|c|c|c|c|c|c|}
\hline No. & Items & SD & & & $\mathbf{N}$ & & & SA \\
\hline 1 & Pure (Sincere) & 1 & 2 & 3 & 4 & 5 & 6 & 7 \\
\hline 2 & Unselfish & 1 & 2 & 3 & 4 & 5 & 6 & 7 \\
\hline 3 & Caring & 1 & 2 & 3 & 4 & 5 & 6 & 7 \\
\hline 4 & Society serving & 1 & 2 & 3 & 4 & 5 & 6 & 7 \\
\hline 5 & Involved & 1 & 2 & 3 & 4 & 5 & 6 & 7 \\
\hline 6 & Proactive & 1 & 2 & 3 & 4 & 5 & 6 & 7 \\
\hline
\end{tabular}

Based on the advertisement/campaign (Appendix 1), please indicate the statements that best describe your opinion based on the scales provided. Please circle only one number for each statement. 


\section{B: Hypermarket's Corporate Social Responsibility (CSR) Image}

\begin{tabular}{|c|c|c|c|c|c|c|c|c|}
\hline No. & Items & SD & & & $\mathbf{N}$ & & & SA \\
\hline 1 & I think this hypermarket has a legitimate (genuine/sincere) interest in this cause. & 1 & 2 & 3 & 4 & 5 & 6 & 7 \\
\hline 2 & This hypermarket is socially responsible. & 1 & 2 & 3 & 4 & 5 & 6 & 7 \\
\hline 3 & This hypermarket is a good corporate citizen. & 1 & 2 & 3 & 4 & 5 & 6 & 7 \\
\hline 4 & Helping others appears to be important to this hypermarket. & 1 & 2 & 3 & 4 & 5 & 6 & 7 \\
\hline 5 & $\begin{array}{l}\text { This promotion benefits "underprivileged individuals" more than it benefits this } \\
\text { hypermarket. }\end{array}$ & 1 & 2 & 3 & 4 & 5 & 6 & 7 \\
\hline
\end{tabular}

\section{C: Consumer-Company Identification (CCI)}

\begin{tabular}{|c|c|c|c|c|c|c|c|c|}
\hline No. & Items & SD & & & $\mathbf{N}$ & & & SA \\
\hline 1 & This hypermarket's principle is similar to my values. & 1 & 2 & 3 & 4 & 5 & 6 & 7 \\
\hline 2 & When someone praises this hypermarket, it feels like a personal compliment. & 1 & 2 & 3 & 4 & 5 & 6 & 7 \\
\hline 3 & When someone criticizes this hypermarket, it feels like a personal insult. & 1 & 2 & 3 & 4 & 5 & 6 & 7 \\
\hline 4 & I am very interested in what others think about this hypermarket. & 1 & 2 & 3 & 4 & 5 & 6 & 7 \\
\hline 5 & $\begin{array}{l}\text { I am concerned about the related information and development of this } \\
\text { hypermarket. }\end{array}$ & 1 & 2 & 3 & 4 & 5 & 6 & 7 \\
\hline 6 & I will spread positive information on this hypermarket to others. & 1 & 2 & 3 & 4 & 5 & 6 & 7 \\
\hline
\end{tabular}

\section{D: Perceived Company-Cause Fit}

\begin{tabular}{|c|c|c|c|c|c|c|c|c|}
\hline No. & Items & SD & & & $\mathbf{N}$ & & & SA \\
\hline 1 & $\begin{array}{l}\text { The "supporting underprivileged individuals" cause implemented by this } \\
\text { hypermarket fits with the nature of its business. }\end{array}$ & 1 & 2 & 3 & 4 & 5 & 6 & 7 \\
\hline 2 & $\begin{array}{l}\text { The "supporting underprivileged individuals" cause implemented by this } \\
\text { hypermarket is relevant to its business. }\end{array}$ & 1 & 2 & 3 & 4 & 5 & 6 & 7 \\
\hline 3 & $\begin{array}{l}\text { The "supporting underprivileged individuals" cause implemented by this } \\
\text { hypermarket is appropriate for its brand image. }\end{array}$ & 1 & 2 & 3 & 4 & 5 & 6 & 7 \\
\hline
\end{tabular}

\section{E: Intention to Participate in Cause-Related Marketing Campaign}

\begin{tabular}{|c|c|c|c|c|c|c|c|c|}
\hline No. & Items & SD & & & $\mathbf{N}$ & & & SA \\
\hline 1 & $\begin{array}{l}\text { I think this hypermarket's campaign of "supporting underprivileged individuals' is } \\
\text { a good idea. }\end{array}$ & 1 & 2 & 3 & 4 & 5 & 6 & 7 \\
\hline 2 & $\begin{array}{l}\text { I would be willing to participate in this hypermarket's campaign of "supporting } \\
\text { underprivileged individuals" by buying most of my groceries from this } \\
\text { hypermarket. }\end{array}$ & 1 & 2 & 3 & 4 & 5 & 6 & 7 \\
\hline 3 & $\begin{array}{l}\text { I would consider purchasing products from this hypermarket that supports a social } \\
\text { cause in order to provide help to the cause. }\end{array}$ & 1 & 2 & 3 & 4 & 5 & 6 & 7 \\
\hline 4 & $\begin{array}{l}\text { It is likely that I would contribute to this hypermarket's campaign of "supporting } \\
\text { underprivileged individuals' by buying most of my groceries from this } \\
\text { hypermarket. }\end{array}$ & 1 & 2 & 3 & 4 & 5 & 6 & 7 \\
\hline
\end{tabular}




\section{Part III - Consumers Behaviour towards Cause-Related Marketing (CRM)}

Please indicate the statements that best describe your opinion based on the scales provided. Please circle only one number for each statement.

\begin{tabular}{|c|c|c|c|c|c|c|}
\hline $\begin{array}{c}\text { Strongly } \\
\text { Disagree (SD) }\end{array}$ & Disagree & $\begin{array}{c}\text { Somewhat } \\
\text { Disagree }\end{array}$ & Neutral (N) & Somewhat Agree & Agree & Strongly Agree (SA) \\
\hline 1 & 2 & 3 & 4 & 5 & 6 & 7 \\
\hline
\end{tabular}

\section{A: Attitude}

\begin{tabular}{|c|c|c|c|c|c|c|c|c|}
\hline No. & Items & SD & & & $\mathbf{N}$ & & & SA \\
\hline 1 & $\begin{array}{l}\text { I like the idea of buying products from a hypermarket which donates part of its profits } \\
\text { to a social cause or NGO. }\end{array}$ & 1 & 2 & 3 & 4 & 5 & 6 & 7 \\
\hline 2 & $\begin{array}{l}\text { I am willing to pay more for a product from a hypermarket if the hypermarket is } \\
\text { donating part of the profits to a social cause. }\end{array}$ & 1 & 2 & 3 & 4 & 5 & 6 & 7 \\
\hline 3 & $\begin{array}{l}\text { If a hypermarket is donating part of its profits to a social cause, then I am more likely } \\
\text { to buy its products. }\end{array}$ & 1 & 2 & 3 & 4 & 5 & 6 & 7 \\
\hline 4 & $\begin{array}{l}\text { Hypermarkets that advertise that they are donating part of their profits to a social cause } \\
\text { are good corporate citizens. }\end{array}$ & 1 & 2 & 3 & 4 & 5 & 6 & 7 \\
\hline
\end{tabular}

\section{B: Subjective Norms}

\begin{tabular}{|c|c|c|c|c|c|c|c|c|}
\hline No. & Items & SD & & & $\mathbf{N}$ & & & SA \\
\hline 1 & $\begin{array}{l}\text { The trend of purchasing products from a hypermarket that supports a social cause } \\
\text { among people around me is increasing. }\end{array}$ & 1 & 2 & 3 & 4 & 5 & 6 & 7 \\
\hline 2 & $\begin{array}{l}\text { People around me generally believe that it is a good idea to purchase products from a } \\
\text { hypermarket that supports a social cause. }\end{array}$ & 1 & 2 & 3 & 4 & 5 & 6 & 7 \\
\hline 3 & $\begin{array}{l}\text { My close friends and family members would appreciate it if I purchased products from } \\
\text { a hypermarket that supports a social cause. }\end{array}$ & 1 & 2 & 3 & 4 & 5 & 6 & 7 \\
\hline 4 & $\begin{array}{l}\text { I would get all the required support (money, time, related information) from friends } \\
\text { and family to purchase products from a hypermarket that supports a social cause. }\end{array}$ & 1 & 2 & 3 & 4 & 5 & 6 & 7 \\
\hline
\end{tabular}

\section{C: Perceived Behavioural Control}

\begin{tabular}{|c|c|c|c|c|c|c|c|c|}
\hline No. & Items & SD & & & $\mathbf{N}$ & & & SA \\
\hline 1 & $\begin{array}{l}\text { I can make the decision independently to purchase products from a hypermarket that } \\
\text { supports a social cause. }\end{array}$ & 1 & 2 & 3 & 4 & 5 & 6 & 7 \\
\hline 2 & $\begin{array}{l}\text { I have the financial capability to purchase products from a hypermarket that supports a } \\
\text { social cause. }\end{array}$ & 1 & 2 & 3 & 4 & 5 & 6 & 7 \\
\hline 3 & $\begin{array}{l}\text { I have the time to go and purchase products from a hypermarket that supports a social } \\
\text { cause. }\end{array}$ & 1 & 2 & 3 & 4 & 5 & 6 & 7 \\
\hline 4 & $\begin{array}{l}\text { I have complete information and awareness regarding where to purchase products from } \\
\text { a hypermarket that supports a social cause. }\end{array}$ & 1 & 2 & 3 & 4 & 5 & 6 & 7 \\
\hline 5 & $\begin{array}{l}\text { Products from a hypermarket that supports a social cause are readily available in the } \\
\text { location where I reside. }\end{array}$ & 1 & 2 & 3 & 4 & 5 & 6 & 7 \\
\hline
\end{tabular}




\section{Part IV - Hypermarket Visit Intention}

Please indicate the statements that best describe your opinion based on the scales provided. Please circle only one number for each of the statements.

\begin{tabular}{|c|c|c|c|c|c|c|c|c|}
\hline No. & Items & SD & & & $\mathbf{N}$ & & & SA \\
\hline 1 & $\begin{array}{l}\text { I would recommend this hypermarket that "supports underprivileged individuals" to } \\
\text { someone who seeks my advice. }\end{array}$ & 1 & 2 & 3 & 4 & 5 & 6 & 7 \\
\hline 2 & $\begin{array}{l}\text { I would say positive things about this hypermarket that "supports underprivileged } \\
\text { individuals" to other people. }\end{array}$ & 1 & 2 & 3 & 4 & 5 & 6 & 7 \\
\hline 3 & $\begin{array}{l}\text { I would encourage friends and relatives to shop at this hypermarket that "supports } \\
\text { underprivileged individuals". }\end{array}$ & 1 & 2 & 3 & 4 & 5 & 6 & 7 \\
\hline 4 & $\begin{array}{l}\text { I will continue to shop at this hypermarket that "supports underprivileged individuals" } \\
\text { in the future. }\end{array}$ & 1 & 2 & 3 & 4 & 5 & 6 & 7 \\
\hline
\end{tabular}




\section{References}

Ajzen, I. (1985). From intentions to actions: $A$ theory of planned behavior (pp. 11-39). Springer Berlin Heidelberg.

Ajzen, I. (1991). The theory of planned behavior. Organizational behavior and human decision processes, 50(2), 179-211.

Alhouti, S., Johnson, C. M., \& Holloway, B. B. (2016). Corporate social responsibility authenticity: Investigating its antecedents and outcomes. Journal of Business Research, 69(3), 1242-1249.

Al-Swidi, A., Mohammed Rafiul Huque, S., Haroon Hafeez, M., \& Noor Mohd Shariff, M. (2014). The role of subjective norms in theory of planned behavior in the context of organic food consumption. British Food Journal, 116(10), 1561-1580.

Anderson, J. C., \& Gerbing, D. W. (1988). Structural equation modeling in practice: A review and recommended two-step approach. Psychological bulletin, 103(3), 411-423.

Anghel, L. D., Grigore, G. F., \& Roşca, M. (2011). Cause-related marketing, part of corporate social responsibility and its influence upon consumers' attitude. Amfiteatru economic, 13(26), 72-85.

Anselmsson, J. (2006). Sources of customer satisfaction with shopping malls: a comparative study of different customer segments. International Review of Retail, Distribution and Consumer Research, 16(1), 115-138.

Anuar, M. M., and Mohamad, O. (2012). Consumer Response to Cause-related Marketing: A Case of Malaysia. Journal of Asian Business Strategy, 2(4), 71-76.

Anuar, M. M., \& Mohamad, O. (2011). Examining the effects of cause-proximity and gender on consumers' response to cause-related marketing: evidence from Malaysia. International Journal of Marketing Studies, 3(3), 174-181.

Arvola, A., Vassallo, M., Dean, M., Lampila, P., Saba, A., Lähteenmäki, L., \& Shepherd, R.
(2008). Predicting intentions to purchase organic food: The role of affective and moral attitudes in the Theory of Planned Behaviour. Appetite, 50(2), 443-454.

Azim, M. T. (2016). Corporate Social Responsibility and employee behavior: mediating role of organizational commitment. Review of Business Management, 18(60), 207-225.

Bamberg, S., Ajzen, I., \& Schmidt, P. (2003). Choice of travel mode in the theory of planned behavior: The roles of past behavior, habit, and reasoned action. Basic and applied social psychology, 25(3), 175-187.

Becker-Olsen, K. L., Cudmore, B. A., \& Hill, R. P. (2006). The impact of perceived corporate social responsibility on consumer behavior. Journal of business research, 59(1), 46-53.

Boenigk, S., \& Schuchardt, V. (2015). Nonprofit collaboration with luxury brands: Positive and negative effects for cause-related marketing. Nonprofit and Voluntary Sector Quarterly, 44(4), 708-733.

Borneo Post Online. (November 24, 2013). Helping the poor to help themselves. Retrieved from http://www.theborneopost.com/2013/11/24/ helping-the-poor-to-help-themselves/

Brewer, M. B. (1991). The social self: On being the same and different at the same time. Personality and social psychology bulletin, 17(5), 475-482.

Brislin, R. W. (1970). Back-translation for cross-cultural research. Journal of cross-cultural psychology, 1(3), 185-216.

Cavazos-Arroyo, J., Puente-Díaz, R., \& Agarwal, N. (2017). An examination of certain antecedents of social entrepreneurial intentions among Mexico residents. Review of Business Management, 19(64), 180-199.

Cavazotte, F. D. S. C. N., de Araujo, F. F., \& de Abreu, A. L. (2017). Organizational identification among Brazilian public employees: a study of the cultural sector. Review of Business Management, 19(64), 289-306. 
Chang, C. T. (2011). Guilt appeals in causerelated marketing: The subversive roles of product type and donation magnitude. International Journal of Advertising, 30(4), 587-616.

Chéron, E., Kohlbacher, F., \& Kusuma, K. (2012). The effects of brand-cause fit and campaign duration on consumer perception of cause-related marketing in Japan. Journal of Consumer Marketing, 29(5), 357-368.

Chin, W. W. (1998). The partial least squares approach to structural equation modeling. Modern methods for business research, 295(2), 295-336.

Cohen, J. (1988). Statistical power analysis for the behavioural sciences. Hillside. New Jersey: Lawrence Earlbaum Associates.

Crisóstomo, V. L., \& Freire, F. D. S. (2015). The Influence of Ownership Concentration on Firm Resource Allocations to Employee Relations, External Social Actions, and Environmental Actions. Review of Business Management, 17(55), 987-1006.

Cruz, B. D. P. A. (2017). Social Boycott. Review of Business Management, 19(63), 5-29.

Cui, Y., Trent, E. S., Sullivan, P. M., \& Matiru, G. N. (2003). Cause-related marketing: How generation $\mathrm{Y}$ responds. International Journal of Retail \& Distribution Management, 31(6), 310-320.

Currás-Pérez, R., Bigné-Alcañiz, E., \& AlvaradoHerrera, A. (2009). The role of self-definitional principles in consumer identification with a socially responsible company. Journal of Business Ethics, 89(4), 547-564.

de Freitas Brandão, I., Diógenes, A. S. M., \& de Abreu, M. C. S. (2017). Value allocation to stakeholder employees and its effect on the competitiveness of the banking sector. Review of Business Management, 19(64), 161-179.

Deng, X., and Xu, Y. (2017). Consumers' Responses to Corporate Social Responsibility Initiatives: The Mediating Role of Consumer-
Company Identification. Journal of Business Ethics, 142(3), 515-526.

Ellen, P. S., Mohr, L. A., \& Webb, D. J. (2000). Charitable programs and the retailer: do they mix?. Journal of retailing, 76(3), 393-406.

Ellen, P. S., Webb, D. J., \& Mohr, L. A. (2006). Building corporate associations: Consumer attributions for corporate socially responsible programs. Journal of the Academy of Marketing Science, 34(2), 147-157.

Euromonitor International. (April, 2014). Grocery Retailers in Malaysia. Passport.

Fishbein, M. A., \& Ajzen, I. (1975). Belief, Attitude, Intention and Behavior: An Introduction to Theory and Research. Addison-Wesley, Reading, MA.

Folse, J. A. G., Niedrich, R. W., \& Grau, S. L. (2010). Cause-relating marketing: The effects of purchase quantity and firm donation amount on consumer inferences and participation intentions. Journal of Retailing, 86(4), 295-309.

Fornell, C., \& Cha, J. (1994). Partial least squares. Advanced methods of marketing research, 407(3), 52-78.

Fornell, C., \& Larcker, D. F. (1981). Evaluating structural equation models with unobservable variables and measurement error. Journal of marketing research, 18(1), 39-50.

Galan Ladero, M. M., Galera Casquet, C., \& Singh, J. (2015). Understanding factors influencing consumer attitudes toward cause-related marketing. International Journal of Nonprofit and Voluntary Sector Marketing, 20(1), 52-70.

Gholami, R., Sulaiman, A. B., Ramayah, T., \& Molla, A. (2013). Senior managers' perception on green information systems (IS) adoption and environmental performance: Results from a field survey. Information \& Management, 50(7), 431-438.

Graham-Rowe, E., Jessop, D. C., \& Sparks, P. (2015). Predicting household food waste reduction using an extended theory of planned behaviour. Resources, Conservation and Recycling, 101, 194-202. 
Grau, S. L., \& Folse, J. A. G. (2007). Causerelated marketing (CRM): The influence of donation proximity and message-framing cues on the less-involved consumer. Journal of Advertising, 36(4), 19-33.

Grewal, D., Baker, J., Levy, M., \& Voss, G. B. (2003). The effects of wait expectations and store atmosphere evaluations on patronage intentions in service-intensive retail stores. Journal of retailing, 79(4), 259-268.

Grolleau, G., Ibanez, L., \& Lavoie, N. (2016). Cause-related marketing of products with a negative externality. Journal of Business Research, 69(10), 4321-4330.

Hair, J. F., Black, W. C., Babin, B. J., Anderson, R. E., \& Tatham, R. (2010). Multivariate Data Analysis. Pearson Education: Upper Saddle River, New Jersey.

Hair, J. F., Hult, G. T. M., Ringle, C. M., \& Sarstedt, M. (2014). A primer on partial least squares structural equation modelling (PLS-SEM). Los Angeles: Sage Publication.

Han, H., Hsu, L. T. J., \& Sheu, C. (2010). Application of the theory of planned behavior to green hotel choice: Testing the effect of environmental friendly activities. Tourism management, 31(3), 325-334.

Hanks, L., Line, N. D., \& Mattila, A. S. (2016). The impact of self-service technology and the presence of others on cause-related marketing programs in restaurants. Journal of Hospitality Marketing \& Management, 25(5), 547-562.

Hsu, C. H., \& Huang, S. S. (2012). An extension of the theory of planned behavior model for tourists. Journal of Hospitality \& Tourism Research, 36(3), 390-417.

Hsu, C. L., Chang, C. Y., \& Yansritakul, C. (2017). Exploring purchase intention of green skincare products using the theory of planned behavior: Testing the moderating effects of country of origin and price sensitivity. Journal of Retailing and Consumer Services, 34, 145-152.
Hu, L. T., \& Bentler, P. M. (1999). Cutoff criteria for fit indexes in covariance structure analysis: Conventional criteria versus new alternatives. Structural equation modeling: a multidisciplinary journal, 6(1), 1-55.

Jin, B., \& Kim, J. O. (2003). A typology of Korean discount shoppers: shopping motives, store attributes, and outcomes. International journal of service Industry Management, 14(4), 396-419.

Kang, J., Alejandro, T. B., \& Groza, M. D. (2015). Customer-company identification and the effectiveness of loyalty programs. Journal of Business Research, 68(2), 464-471.

Kropp, F., Holden, S. J., \& Lavack, A. M. (1999). Cause-related marketing and values in Australia. International Journal of Nonprofit and Voluntary Sector Marketing, 4(1), 69-80.

Lacey, R., Kennett-Hensel, P. A., \& Manolis, C. (2015). Is corporate social responsibility a motivator or hygiene factor? Insights into its bivalent nature. Journal of the Academy of Marketing Science, 43(3), 315-332.

La Ferle, C., Kuber, G., \& Edwards, S. M. (2013). Factors impacting responses to cause-related marketing in India and the United States: Novelty, altruistic motives, and company origin. Journal of Business Research, 66(3), 364-373.

Lafferty, B. A., \& Edmondson, D. R. (2014). A note on the role of cause type in cause-related marketing. Journal of Business Research, 67(7), 1455-1460.

Lam, T., and Hsu, C. H. (2006). Predicting behavioral intention of choosing a travel destination. Tourism management, 27(4), 589599.

Langen, N., Grebitus, C., \& Hartmann, M. (2013). Success Factors of Cause-Related Marketing in Germany. Agribusiness, 29(2), $207-$ 227.

Lii, Y. S., \& Lee, M. (2012). Doing right leads to doing well: When the type of CSR and reputation 
interact to affect consumer evaluations of the firm. Journal of Business Ethics, 105(1), 69-81.

Liu, G., \& Ko, W. W. (2011). An analysis of cause-related marketing implementation strategies through social alliance: Partnership conditions and strategic objectives. Journal of business ethics, $100(2), 253-281$.

Lorenz, B. A., Hartmann, M., \& Simons, J. (2015). Impacts from region-of-origin labeling on consumer product perception and purchasing intention-Causal relationships in a TPB based model. Food Quality and Preference, 45, 149-157.

Luna, I. R. D., Montoro-Ríos, F., LiébanaCabanillas, F., \& Luna, J. G. D. (2017). NFC technology acceptance for mobile payments: A Brazilian Perspective. Review of Business Management, 19(63), 82-103.

Mael, F., \& Ashforth, B. E. (1992). Alumni and their alma mater: A partial test of the reformulated model of organizational identification. Journal of organizational Behavior, 13(2), 103-123.

Malay Mail Online. (January 23, 2016). The poor must help themselves, ministry says. Retrieved from http://www.themalaymailonline.com/ malaysia/article/the-poor-must-help-themselvesministry-says

Ministry of Domestic Trade and Consumer Affair (2018). Official Portal. Retrieved from https:// www.kpdnkk.gov.my/kpdnkk/?lang=en

Moosmayer, D. C., and Fuljahn, A. (2010). Consumer perceptions of cause related marketing campaigns. Journal of Consumer Marketing, 27(6), 543-549.

Moosmayer, D. C., \& Fuljahn, A. (2013). Corporate motive and fit in cause related marketing. Journal of Product \& Brand Management, 22(3), 200-207.

Nunnally, J. C., \& Bernstein, I. H. (1994). Psychological theory. New York: McGraw-Hill.

Olorunniwo, F., Hsu, M. K., \& Udo, G. J. (2006). Service quality, customer satisfaction, and behavioral intentions in the service factory. Journal of Services Marketing, 20(1), 59-72.
Pan, Y., \& Zinkhan, G. M. (2006). Determinants of retail patronage: a meta-analytical perspective. Journal of retailing, 82(3), 229-243.

Park, E., Kim, K. J., \& Kwon, S. J. (2017). Corporate social responsibility as a determinant of consumer loyalty: An examination of ethical standard, satisfaction, and trust. Journal of Business Research, 76, 8-13.

Patel, J. D., Gadhavi, D. D., \& Shukla, Y. S. (2017). Consumers' responses to cause related marketing: moderating influence of cause involvement and skepticism on attitude and purchase intention. International Review on Public and Nonprofit Marketing, 14, 1-18.

Patrus, R., de Carvalho Neto, A. M., Coelho, H. M. Q., \& de Sousa Teodósio, A. D. S. (2013). Corporate Social Responsibility and labor relations: a research agenda about internal stakeholders management in UN's global compact signatory corporations. Review of Business Management, 15(46), 22-38.

Pookulangara, S., Hawley, J., and Xiao, G. (2011). Explaining consumers' channel-switching behavior using the theory of planned behavior. Journal of Retailing and Consumer Services, 18(4), 311-321.

Potdar, B., Guthrie, J., \& Gnoth, J. (2018). Encouraging shoplifting prevention with quality relationships: A theory of planned behaviour perspective. International Journal of Retail \& Distribution Management, 46(1), 49-69.

Ringle, C. M., Wende, S., \& Becker, J-M. (2015). "SmartPLS 3," www.smartpls.com

Robinson, S. R., Irmak, C., and Jayachandran, S. (2012). Choice of cause in cause-related marketing. Journal of Marketing, 76(4), 126-139.

Saeidi, S. P., Sofian, S., Saeidi, P., Saeidi, S. P., $\&$ Saaeidi, S. A. (2015). How does corporate social responsibility contribute to firm financial performance? The mediating role of competitive advantage, reputation, and customer satisfaction. Journal of Business Research, 68(2), 341-350. 
Samu, S., \& Wymer, W. (2009). The effect of fit and dominance in cause marketing communications. Journal of Business Research, 62(4), 432-440.

Sen, S., \& Bhattacharya, C. B. (2001). Does doing good always lead to doing better? Consumer reactions to corporate social responsibility. Journal of marketing Research, 38(2), 225-243.

Soni, S., \& Soni, A. (2013, July). Cause Related Marketing: A Strategy to Communicate Corporate Social Responsibility. In PRIMA (Vol. 4, No. 1). Publishing India Group.

The Ministry of Higher Education and Bank Negara Malaysia (2017). Outlook and Policy in 2017. Retrieved from http://www.bnm.gov.my/ files/publication/ar/en/2016/cp04_003_box.pdf

The Star Online. (August 3, 2013). Malaysia's income distribution inequality 'still high'. Retrieved from http://www.thestar.com.my/business/ business-news/2013/08/03/malaysias-incomedistribution-inequality-still-high/

The Star Online. (March 24, 2016). Lower income group most effected by inflation. Retrieved from http://www.thestar.com.my/business/businessnews/2016/03/24/lower-income-group-mostaffected-by-inflation/

The Star Online. (May 9, 2018). Average wages of Malaysians on the Rise. Retrieved from https://www.thestar.com.my/business/businessnews/2018/05/09/average-wages-on-the-rise/

Ting, H., Cyril de Run, E., \& Thurasamy, R. (2015). Young Adults' Attitude Towards Advertising: a multi-group analysis by ethnicity. Review of Business Management, 17(54), 769-787.

Van den Brink, D., Odekerken-Schröder, G., \& Pauwels, P. (2006). The effect of strategic and tactical cause-related marketing on consumers' brand loyalty. Journal of Consumer Marketing, 23(1), 15-25.

Vanhamme, J., Lindgreen, A., Reast, J., \& van Popering, N. (2012). To do well by doing good: Improving corporate image through cause-related marketing. Journal of business ethics, 109(3), 259274.

Varadarajan, P. R., \& Menon, A. (1988). Causerelated marketing: A coalignment of marketing strategy and corporate philanthropy. The Journal of Marketing, 52(3), 58-74.

Verbeke, W., \& Vackier, I. (2005). Individual determinants of fish consumption: application of the theory of planned behaviour. Appetite, 44(1), 67-82.

Watanabe, T., Berry, T. R., Willows, N. D., \& Bell, R. C. (2015). Assessing intentions to eat low-glycemic index foods by adults with diabetes using a new questionnaire based on the theory of planned behaviour. Canadian journal of diabetes, 39(2), 94-100.

Wholesale and Retail. (2013). Economic Transformation Programme. Performance Management and Delivery Unit (PEMANDU). Retrieved from http://etp.pemandu.gov. my/Wholesales_-\%E2\%97\%98-_Retail-@Wholesale_and_Retail.aspx

Wu, J. H., Li, S. H., \& Sung, W. Y. (2016). The study of perceived environment and its relation to senior citizen's physical activity behavior intention. Journal of Business Research, 69(6), 2259-2264.

Wu, W. Y., \& Tsai, C. H. (2008). The empirical study of CRM: Consumer-company identification and purchase intention in the direct selling industry. International Journal of Commerce and Management, 17(3), 194-210.

Yusta, A. I., Ruiz, M. P. M., \& Zarco, A. I. J. (2011). The Role of the Convenience and the Subjective Norm in the Intention of Purchase Across Internet (B2C): an application in the hospitality industry. Review of Business Management, 13(39), 137-158.

Zhu, L., He, Y., Chen, Q., \& Hu, M. (2017). It's the thought that counts: The effects of construal level priming and donation proximity on consumer response to donation framing. Journal of Business Research, 76, 44-51. 
About the Authors:

1. [Kay Tze Hong, Doctor of Philosophy in Business Economics, University Putra Malaysia, Serdang, Malaysia. E-mail: hongkaytze@gmail.com]

ORCID

(iD $0000-0002-9336-4131$

2. [Siew Imm Ng, Doctor of Philosophy in Management, University of Western Australia, Perth, Australia.

E-mail:imm_ns@upm.edu.my]

ORCID

(DD0000-0002-6518-925X

3. [Raja Nerina Raja Yusof, Doctor of Philosophy in Management, University of Otago, Dunedin, New Zealand. E-mail: nerina@upm.edu.my]

ORCID

(iD 0000-0002-6768-2865

4. [Shivee Ranjanee Kaliappan, Doctor of Philosophy in Economics, International Islamic University of Malaysia, Kuala Lumpur, Malaysia. E-mail: shivee@upm.edu.my]

ORCID

(iD)0000-0001-6953-7541

Has any preliminary version of this article been presented / published in annals of scientific congresses or is it derived from a thesis or dissertation?

No

\section{Acknowledgement}

This research was supported by a Universiti Putra Malaysia Grant (GP-IPB/2014/9441000).

\section{Contribution of each author}

\begin{tabular}{|c|c|c|c|c|}
\hline Contribution & $\begin{array}{l}\text { Kay Tze } \\
\text { Hong }\end{array}$ & $\begin{array}{l}\text { Siew Imm } \\
\quad \mathrm{Ng}\end{array}$ & $\begin{array}{l}\text { Raja Nerina } \\
\text { Raja Yusof }\end{array}$ & $\begin{array}{l}\text { Shivee Ranjanee } \\
\text { Kaliappan }\end{array}$ \\
\hline 1. Definition of research problem & $\sqrt{ }$ & $\sqrt{ }$ & $\sqrt{ }$ & $\sqrt{ }$ \\
\hline $\begin{array}{l}\text { 2. Development of hypotheses or research questions (empirical } \\
\text { studies) }\end{array}$ & $\sqrt{ }$ & $\sqrt{ }$ & & $\sqrt{ }$ \\
\hline 3. Development of theoretical propositions (theoretical work) & $\sqrt{ }$ & $\sqrt{ }$ & & \\
\hline 4. Theoretical foundation/Literature review & $\sqrt{ }$ & & & \\
\hline 5. Definition of methodological procedures & $\sqrt{ }$ & $\sqrt{ }$ & $\sqrt{ }$ & \\
\hline 6. Data collection & $\sqrt{ }$ & & & \\
\hline 7. Statistical analysis & $\sqrt{ }$ & & & \\
\hline 8. Analysis and interpretation of data & $\sqrt{ }$ & & & \\
\hline 9. Critical revision of the manuscript & & $\sqrt{ }$ & $\sqrt{ }$ & $\sqrt{ }$ \\
\hline 10. Manuscript writing & $\sqrt{ }$ & $\sqrt{ }$ & & \\
\hline 11. Other (please specify which) & & & & \\
\hline
\end{tabular}

